\title{
Indian Spices and their Medicinal Value
}

\author{
Sonal Dubey \\ Krupanidhi College of Pharmacy, Chikkabellandur, Carmelaram Post, Bangalore, INDIA
}

\section{History of Spice}

The history of spices is the history of humankind itself, with empires rising and falling based on the trade of exotic spices from distant lands, their intoxicating allure changing and shaping the very foundations of our society. Christopher Columbus set sail for the Indies (following the unorthodox notion of getting there faster by heading in exactly the wrong direction), he was searching for pepper. Not gold or jewels, but pepper and other spices. He never found the passage to the Indies he was hoping for, and he never found the pepper he was searching for, but the world was changed forever because of our passion for strange new flavours from faraway places.

The spice trade developed throughout South Asia and Middle East by at least 2000 BCE with cinnamon and black pepper, and in East Asia with herbs and pepper. The Egyptians used herbs for mummification and their demand for exotic spices and herbs helped stimulate world trade. The word spice comes from the Old French word espice, which became epice, and which came from the Latin root spec, the noun referring to "appearance, sort, kind": species has the same root. By 1000 BCE, medical systems based upon herbs could be found in China, Korea, and India. Early uses were connected with magic, medicine, religion, tradition, and preservation.

A spice is a seed, fruit, root, bark, or other plant substance primarily used for flavouring, colouring or preserving food. Spices are distinguished from herbs, which are the leaves, flowers, or stems from plants used for flavouring or as a garnish. Sometimes, spices may be ground into a powder for convenience.

Right from the kitchen and medicinal uses in homes spices have an important role to play in different places. As India is blessed with a varied climate each of its state produces some spice or the other. No wonder why spices are used so extensively for cooking in India. Not only in India but also in some other countries spices are considered to be of great use.

Apart from adding colour, flavour and taste, consumption of spices provide infinite health benefits. You can be more creative in use of spices if you know its uses better. Some may be a substitute for your costly beauty products and even medicines.

\section{Commerce of spice}

In world trade of spices India is at number three with $8.8 \%$ of the share. The major spices exported by India are Chillies (40\%), Turmeric (10\%), Cumin (10\%), Coriander (9.5\%), Fenugreek (4.2\%), Peppers (4\%) and others (19\%). Though these spices provide innumerable benefits they should be used sparingly. The excessive use of spices in food can cause harm to the health. Try to make specific use of these spices. This will help to make optimal use of the resources provided by nature. Strike the right balance and add some spice to your life.

\section{REFERENCES}

1. Rathore SS, Saxena SN, Singh B. Potential Health Benefits of Major Seed Spices, International J. Seed Spices. 2013;3(2):1-12.
DOI: 10.5530/ijper.51.3s.41

Correspondence:

Sonal Dubey,

Krupanidhi College of

Pharmacy, Chikkabellandur,

Carmelaram Post,

Bangalore, INDIA.

Phone no: 9035500090

E-mail: drsonaldubey@

gmail.com 
List of the important Indian Spices, their uses and benefits.

\begin{tabular}{|c|c|c|}
\hline Spices & Uses & Benefits \\
\hline $\begin{array}{l}\text { Cardamom } \\
\text { (Elaichi) }\end{array}$ & $\begin{array}{l}\text { It is used in most of the Indian and other sweet } \\
\text { dishes to give a good flavour and smell. It is also } \\
\text { used widely in pharmaceutical sector. }\end{array}$ & $\begin{array}{l}\text { Helps to control bad breath and digestive disorder. A whole } \\
\text { cardamom chewed is good for coping with diabetes. }{ }^{1}\end{array}$ \\
\hline Chilli (Lal Mirch) & $\begin{array}{l}\text { It is a main ingredient used for adding hot flavour } \\
\text { to the food. }\end{array}$ & $\begin{array}{l}\text { The antioxidants present in chilli help to cope with cholesterol. } \\
\text { It also helps burning calories. }{ }^{2}\end{array}$ \\
\hline $\begin{array}{l}\text { Cinnamon } \\
\text { (Dalchini) }\end{array}$ & $\begin{array}{l}\text { It is used for mainly for seasoning food and } \\
\text { preparing masalas It has medicinal uses too. }\end{array}$ & $\begin{array}{l}\text { It supports natural production of insulin and reduces blood } \\
\text { cholesterol }\end{array}$ \\
\hline Clove (Laung) & $\begin{array}{l}\text { It is used as a cooking ingredient mainly for } \\
\text { seasoning or preparing Masalas. }\end{array}$ & $\begin{array}{c}\text { Clove oil is beneficial for coping with tooth ache and sore } \\
\text { gums. It is also beneficial remedy for chest pains, fever, } \\
\text { digestive problems, cough and cold. }{ }^{3}\end{array}$ \\
\hline $\begin{array}{l}\text { Coriander } \\
\text { (Dhaniya) }\end{array}$ & $\begin{array}{l}\text { Coriander leaves as well as coriander seeds are } \\
\text { used in cooking. It also has some medicinal uses. }\end{array}$ & $\begin{array}{l}\text { It can be used externally on aching joints and rheumatism. It } \\
\text { is also good for coping with soar throat, allergies, digestion } \\
\text { problems, hay fever etc. }\end{array}$ \\
\hline Cumin (Zeera) & $\begin{array}{l}\text { It is used for cooking and it also possesses } \\
\text { medicinal properties. }\end{array}$ & $\begin{array}{l}\text { It is a good source or iron and keeps immune system healthy. } \\
\text { Water boiled with cumin seeds is good for coping with } \\
\text { dysentery. }\end{array}$ \\
\hline $\begin{array}{l}\text { Fenugreek } \\
\text { (Methi) }\end{array}$ & $\begin{array}{l}\text { It is mainly used as a green leafy vegetable and } \\
\text { seeds are used for seasoning and preparing } \\
\text { Masalas. It also has medicinal uses. }\end{array}$ & $\begin{array}{c}\text { Fenugreek seed tea or sweet fudge is good for increasing } \\
\text { breast milk. It also helpful for treating diabetes and lowering } \\
\text { cholesterol. }{ }^{4}\end{array}$ \\
\hline Garlic (Lassan) & $\begin{array}{l}\text { It is used for cooking as well as for the medicinal } \\
\text { purpose. }\end{array}$ & $\begin{array}{l}\text { It is useful for coping with cough and cold. It also has } \\
\text { antibiotic properties. }\end{array}$ \\
\hline Ginger (Adrak) & $\begin{array}{l}\text { It is used for giving a specific flavour to food and } \\
\text { has many medicinal uses. }\end{array}$ & $\begin{array}{l}\text { Helps to avoid digestive problems. It is beneficial for coping } \\
\text { with cough and cold. }\end{array}$ \\
\hline $\begin{array}{l}\text { Bishop's weed } \\
\text { (Ajwain) }\end{array}$ & $\begin{array}{l}\text { It is used for seasoning and as flavorant as well as } \\
\text { medicinal purpose }\end{array}$ & $\begin{array}{l}\text { Used in GI ailments including: diarrhoea, dyspepsia, } \\
\text { flatulence, indigestion and cholera. In Ayurvedic medicine } \\
\text { it is used as an antiseptic, preservative, respiratory and GI } \\
\text { ailments. Unani system of medicine as an enhancer of the } \\
\text { body's resistance. }{ }^{5,6}\end{array}$ \\
\hline Nutmeg (Jaiphal) & $\begin{array}{c}\text { It is used in powdered form for garnishing and } \\
\text { also for masala preparation. It is used in soaps, } \\
\text { perfumes and shampoos. It can also be used for } \\
\text { medicinal purpose. }\end{array}$ & $\begin{array}{l}\text { It is beneficial for the treatments of asthma, heart disorder and } \\
\text { bad breath. }\end{array}$ \\
\hline $\begin{array}{l}\text { Pepper (Kaali } \\
\text { Mirch) }\end{array}$ & $\begin{array}{l}\text { It is extensively used in cooking, especially for } \\
\text { garnishing. It is has many medicinal uses too. }\end{array}$ & $\begin{array}{l}\text { It helps coping with cold, cough, infections etc. It helps to deal } \\
\text { with muscle pains and digestive problems. }\end{array}$ \\
\hline $\begin{array}{l}\text { Saffron (Zaffran/ } \\
\text { Kesar) }\end{array}$ & $\begin{array}{c}\text { It is used for cooking as well as in beauty products. } \\
\text { It is mainly used in sweet dishes. It has good } \\
\text { medicinal properties. }\end{array}$ & $\begin{array}{l}\text { It helps to cope with skin diseases. It is a good remedy for } \\
\text { cough, cold and asthma. }\end{array}$ \\
\hline $\begin{array}{c}\text { Star anise } \\
\text { (Chakra Phool) }\end{array}$ & It is used in cooking and for medicinal purpose & $\begin{array}{c}\text { Star anise oil is beneficial for rheumatism. It is helpful for } \\
\text { digestion and avoiding bad breath }\end{array}$ \\
\hline Turmeric (Haldi) & $\begin{array}{c}\text { It is used in cooking and skin care products. It has } \\
\text { wide range medicinal uses. }\end{array}$ & $\begin{array}{l}\text { It helps deal with skin problems. Turmeric powder can be } \\
\text { used for healing cuts and wounds. It also makes coping with } \\
\text { diabetes easier. }\end{array}$ \\
\hline
\end{tabular}

2. Kosuge $\mathrm{S}$, Inagaki $\mathrm{Y}$, Okumura $\mathrm{H}$. Studies on the pungent principles of red pepper. Part VIII. On the chemical constitutions of the pungent principles, J. Agric. Chem. Soc. 1961;35:923-7.

3. Chaieb K, Hajlaoui H, Zmantar T, Kahla-Nakbi AB, Rouabhia M, Mahdouani $\mathrm{K}$, et al. The chemical composition and biological activity of clove essential oil, Eugenia caryophyllata (Syzigium aromaticum L. Myrtaceae): a short review, Phytother Res. 2007:21(6):501-6.

4. Suresh P, Kavitha N, Babu SM, Reddy VP, Latha AK. Effect of ethanol extract of Trigonella foenum graecum (Fenugreek) seeds on Freund's adjuvantinduced arthritis in albino rats., Inflammation. 2012;35(4):1314-21.
5. Perry R, Hunt K, Ernst E. Nutritional supplements and other complementary medicines for infantile colic: a systematic review, Pediatrics. 2011;127(4):72073.

6. Chauhan B, Kumar G, Ali M. A Review on phytochemical constituents and activities of Trachyspermum ammi (L.) sprague fruits. AJPTR. 2012;2(4):32940.

7. Venugopal DVR, Yarla NS, Umadevi P. Synthesis of novel piperine analogues of dipeptidylboronic acid as antimicrobial and anticancer agents, Med. Chem. 2014;4(9):606-10.

8. Tayyem RF, Heath DD, Al-Delaimy WK, Rock CL. Curcumin content of turmeric and curry powders. Nutr Cancer. 2006;55(2):126-31. 


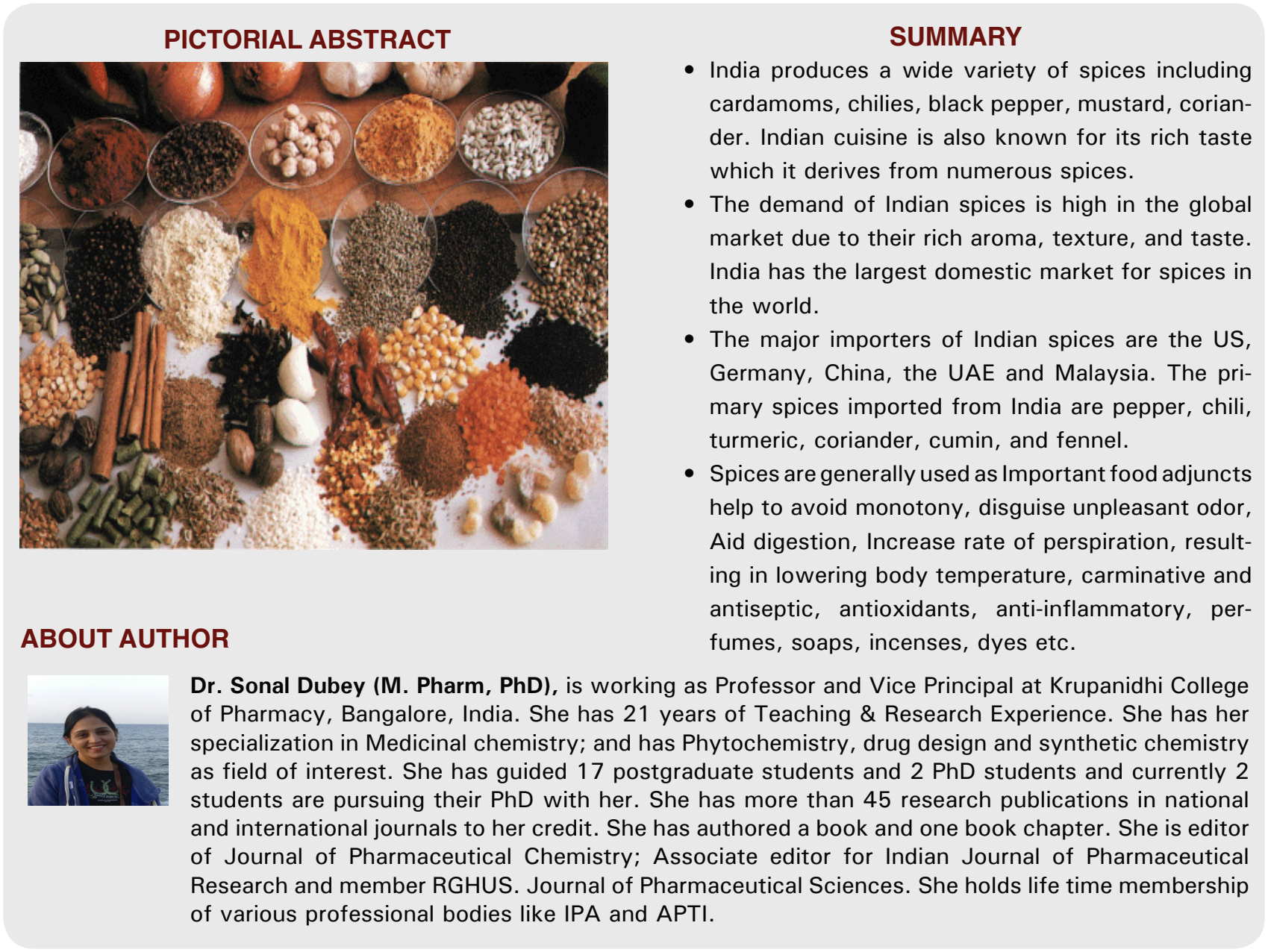

Cite this article: Sonal Dubey. Indian Spices and their Medicinal Value. 2017;51(3)Suppl:S330-32. 